CASE REPORT

\title{
Chronic Hepatitis Due to Gluten Enteropathy - a Case Report
}

\author{
Irina I. Ivanova ${ }^{1,2}$, Denitsa Y. Dukova ${ }^{1,2}$, Pavlina G. Boikova ${ }^{1,2}$, LiliS. Grudeva ${ }^{2}$, Ivan B.Shalev ${ }^{1,2}$, \\ Iskren A. Kotzev ${ }^{1,2}$
}

${ }^{1}$ Department of Internal Medicine, Prof. Paraskev Stoyanov Medical University, Varna, Bulgaria

${ }^{2}$ Clinic of Gastroenterology, St. Marina University Hospital, Varna, Bulgaria

\section{Correspondence:}

Irina I. Ivanova, Department of Internal Medicine, Prof Paraskev Stoyanov Medical University, Varna, 1 Hristo Smirnenski Blvd., 9010 Varna, Bulgaria

E-mail: irinaiivanova@abv.bg

Tel: +359888 842505

Received: 16 Feb 2016

Accepted: 09 Nov 2016

Published Online: 06 March 2017

Published: 27 June 2017

Key words: gluten enteropathy, hepatitis, liver enzymes

Citation: Ivanova II, Dukova DY, Boikova PG, Grudeva LS, Shalev IB, Kotzev IA. Chronic hepatitis due to gluten enteropathy - a case report.

Folia Medica 2017;59(2):228-231. doi: 10.1515/folmed-2017-0025
Background: Celiac disease is an immune-mediated enteropathy precipitated by exposure to dietary gluten in genetically predisposed individuals.

Case description: A 45-year-old Caucasian woman presented with severe iron-deficient anemia and mild elevation of liver enzymes. Upper endoscopy was done in the context of evaluation of anemia, which revealed reduced duodenal folds and mosaic pattern of the mucosa, but also grade II esophageal varices and portal hypertensive gastropathy. Duodenal biopsy showed total villous atrophy, diffuse mainly lymphocytic infiltrate, presence of intra-epithelial lymphocytes. Serology test confirmed celiac disease by the typical pattern of high titer positive $\lg \mathrm{A}$ and IgG antibodies to tissue transglutaminase. Liver biopsy was performed for staging and etiological evaluation, because laboratory screening ruled out common viral, metabolic and autoimmune liver disease. Liver morphology was consistent with chronic hepatitis without findings for extensive fibrosis. Our patient had poor dietary compliance, so we failed to established improvement of liver enzymes and resolution of anemia during follow-up.

Conclusions: We would like to stress on the diverse clinical manifestations of celiac disease and the importance of serologic screening with antibodies to tissue transglutaminase in differential diagnosis of chronic liver disease.

\section{BACKGROUND}

Gluten enteropathy (GE) or celiac disease is a chronic disorder that is caused by an inflammatory $\mathrm{T}$ cell response to proteins in wheat, rye and barley (collectively called gluten). It is characterized by the presence of typical autoantibodies to human tissue transglutaminase (TTG) and histologic alterations of the small bowel mucosa. Currently, GE is known as a multi-organ inflammatory disorder that can present at any age. ${ }^{1}$ The prevalence in the European population is $0.5 \%$ to $1.0 \%$. GE is frequently unrecognized because of the diversity of symptoms and disease presentations. A wide spectrum of liver injuries in children and adults were known as related to $\mathrm{GE}^{2}{ }^{2}$ - Mild elevation of aminotransferase activity and non-specific histological changes ("reactive" hepatitis) reverting to normal after 6-12 months on a strict gluten-free diet;

- Non-alcoholic fatty liver disease, related to malnutrition, mainly reversible steatosis;

- Chronic active hepatitis of autoimmune mechanism with progressive outcome, as autoimmune hepatitis or biliary hepatitis, generally unaffected by gluten withdrawal.

- A severe acute liver failure potentially treatable by a gluten-free diet.

Although mild liver dysfunction frequently occurs in patients with GE, progressing liver disease to cirrhosis are rare. ${ }^{3,4}$

\section{CASE DESCRIPTION}

A 45-year-old woman was referred to the Gastroenterology Clinic for evaluation of anemia and chronic hepatitis. She was frequently admitted to our hospital over the last 10 years for fatigue, arthralgia, headache, genital bleeding and chronic anemia. Anemia persisted despite iron supplementation and surgical treatment of uterine fibroids (in 2009) as a possible source of bleeding. Although abdominal symptoms were not predominant, she reported variable mild diarrhea, bloating and loss of appetite since 2005. Family history was negative for neoplastic and 
autoimmune disorders. Alcohol and hepatotoxic substances intake were excluded. She had stable body weight (BMI, 26) and was in good general condition. Physical signs of the disease were pale skin, mild diffuse enlargement of thyroid gland, firm hepatomegaly and mild foot edema. Laboratory tests were consistent with severe chronic microcytic anemia (hemoglobin $\sim 70 \mathrm{~g} / \mathrm{l}, \mathrm{MCV} 69 \mathrm{fl}$, serum iron $2.3 \mu \mathrm{mol} / \mathrm{l})$. Except for iron deficiency, there was no other laboratory abnormality suggestive for malabsorption. Electrophoresis of hemoglobin excluded thalassemia. It should be noticed the presence of transaminase elevation (predominantly AST, up to 3 times the upper limit of normal) and increased AP up to 3 times upper limit of normal. Laboratory investigations were collected from medical reports and summarized in Table $\mathbf{1}$.

Based on laboratory data for chronic hepatitis, further tests were performed to established etiology, however viral, autoimmune and metabolite liver diseases were excluded. (Table 2).

Abdominal ultrasound exam registered moderate liver steatosis, increased liver dimensions, normal spleen size, Doppler signs for initial portal hypertension (portal vein diameter $11 \mathrm{~mm}$ and flow 0.71 l/min; superior mesenteric vein diameter $19 \mathrm{~mm}$, flow $0.49 \mathrm{l} / \mathrm{min}$ and spleen vein diameter $8 \mathrm{~mm}$, flow $0.34 \mathrm{l} / \mathrm{min}$ ). Liver biopsy was done in Feb/2009 showing evidence of portal lymph and plasma cell infiltration, mild lobular inflammation, grade I steatosis, absence of fibrosis. Upper endoscopy in 2009 revealed esophageal varices (grade I) and antral chronic gastritis with atrophy due to Helicobacter pylori infection. Repeated upper endoscopy established esophageal varices (grade II), portal hypertensive gastropathy, nodularity and mosaic pattern of the distal duodenal mucosa. Biopsies obtained from distal part of duodenum showed to- tal villous atrophy, diffuse infiltrate with numerous intraepithelial lymphocytes. Further investigation of serology tests for GE revealed highly (+) TTG $\operatorname{IgA}$ and IgG antibodies. Based on typical findings finally in 2012, GE was diagnosed, in association with chronic hepatitis, transition to compensated cirrhosis. The following differential diagnoses were considered: latent hepatitis $B$ infection; congenital liver fibrosis; autoimmune hepatitis in the absence of non-organ-specific autoantibodies; primary biliary cirrhosis or sclerosing cholangitis; inflammatory bowel disease; tuberculosis; sarcoidosis. Our patient had poor dietary compliance, so we failed to established improvement of liver enzymes and resolution of anemia during follow-up.

\section{DISCUSSION}

GE is a common chronic disease, often cited as an "iceberg" phenomenon, even discussed in differential diagnosis of almost every GIT disorder. Recently, atypical or asymptomatic manifestations are becoming more commonly described. ${ }^{1}$ Liver involvement varies from nonspecific hepatitis, chronic active hepatitis, steatohepatitis to frank cirrhosis. ${ }^{2-6}$ Liver function tests abnormalities have been reported in $17.5 \%$ to $40 \%$ of newly diagnosed GE patients. ${ }^{7-8}$ A strict gluten-free diet leads to normalization of transaminases in the majority (approximately $80 \%$ ) of studied adults with GE. In the persons with persistent hypertransaminasemia despite gluten exclusion, coexisting liver disease may be established. ${ }^{4,8} \mathrm{~A}$ Swedish epidemiological study registered an eightfold increased risk of mortality of liver cirrhosis in patients with GE. ${ }^{9}$

In our case, we found no obvious cause for advanced liver disease and the negative auto-antibodies made it impossible to firmly establish the diagnosis of autoimmune hepatitis. Magnetic

Table 1. Summary of routine laboratory tests, according to available medical records

\begin{tabular}{ccccccccccc}
\hline Date & $\begin{array}{c}\text { ESR } \\
\mathrm{mm} / \mathrm{h}\end{array}$ & $\begin{array}{c}\text { Hemoglobin } \\
\mathrm{g} / 1\end{array}$ & $\begin{array}{c}\text { WBC } \\
10^{9} / 1\end{array}$ & $\begin{array}{c}\text { PIt } \\
10^{9} / 1\end{array}$ & $\begin{array}{c}\text { AST } \\
\text { IU/1 }\end{array}$ & $\begin{array}{c}\text { ALT } \\
\text { IU/1 }\end{array}$ & $\begin{array}{c}\gamma \text { GT } \\
\text { IU/1 }\end{array}$ & $\begin{array}{c}\text { AP } \\
\text { IU/1 }\end{array}$ & $\begin{array}{c}\text { Bilirubin } \\
\mu \mathrm{mol} / 1\end{array}$ & $\begin{array}{c}\text { Cholinesterase } \\
\text { IU/1 }\end{array}$ \\
\hline$/ 10 / 2005$ & 80 & 70 & 4.9 & 515 & 51 & 40 & & & 7.7 & \\
$/ 02 / 2006$ & 60 & 69 & 3.7 & 313 & 43 & 44 & 66 & 466 & & 6000 \\
$/ 02 / 2009$ & 85 & 66 & 4.5 & 297 & 54 & 47 & 52 & 688 & 4.0 & 5763 \\
$/ 08 / 2012$ & 70 & 103 & 4.9 & 349 & 101 & 78 & 124 & 393 & 5.0 & \\
$/ 08 / 2013$ & 100 & 102 & 4.5 & 415 & 67 & 59 & 71 & 330 & & \\
$/ 10 / 2013$ & 75 & 100 & 4.2 & 440 & 47 & 64 & & & & \\
\hline
\end{tabular}


Table 2. Results of laboratory tests for etiological evaluation of chronic liver disease

\begin{tabular}{llc}
\hline \multicolumn{1}{c}{ Possible etiology } & \multicolumn{1}{c}{ Screen lab test } & Patient's results \\
\hline Chronic viral hepatitis B & HBsAg & $(-)$ \\
& Anti HBc IgG antibodies & $(+)$ \\
Chronic viral hepatitis C & Anti HCV antibodies & $(-)$ \\
Autoimmune hepatitis & IgG level & Normal \\
& Autoantibodies: ANA, SMA, LKMA & $(-)$ \\
Primary biliary cirrhosis & Autoantibodies: AMA & $(-)$ \\
Wilson's disease & Ceruloplasmin, serum and urine & Normal \\
Hereditary hemochromatosis & Copper concentration & Low level \\
Alcoholic steatohepatitis & Serum iron, ferritin & $(-)$ \\
Nonalcoholic steatohepatitis & $\uparrow$ MCV, $\uparrow \gamma$ GT, AST/ALT>2 & Normal tests \\
\hline
\end{tabular}

resonance cholangiopancreatography is advisable for excluding primary biliary cholangitis but in our patient biliary tract disease was excluded based on abdominal ultrasound follow-up and lack of liver biopsy findings for chronic cholestasis. The causal relationship with GE, if any, remains unproven. GE was established after a 7-year follow-up. Unfortunately, the patient had shown poor compliance to gluten-free diet.

Literature reviews discuss GE as underlying cause of unexplained elevations of liver enzymes. ${ }^{3,10}$ Most patients lack overt gastrointestinal symptoms. Therefore, serologic screening of GE should be included in differential diagnosis of chronic liver disease of unknown origin.

\section{REFERENCES}

1. Kelly CP, Bai JC, Liu E, et al. Advances in diagnosis and management of celiac disease. Gastroenterology 2015;148(6):1175-86.

2. Rubio-Tapia A, Murray JA. Liver involvement in celiac disease. Minerva Med 2008;99(6):595-604.

3. Lo Iacono O, Petta S, Venezia G, et al. Anti-tissue transglutaminase antibodies in patients with abnormal liver tests: is it always coeliac disease? Am J
Gastroenterol 2005;100(11):2472-7.

4. Singh P, Agnihotri A, Jindal G, et al. Celiac disease and chronic liver disease: Is there a relationship? Indian J Gastroenterol 2013;32(6):404-8.

5. Anania C, De Luca E, De Castro G, et al. Liver involvement in pediatric celiac disease. World $\mathrm{J}$ Gastroenterol 2015;21(19):5813-22.

6. Caprai S, Vajro P, Ventura A, et al. Autoimmune liver disease associated with celiac disease in childhood:a multicenter study. Clin Gastroenterol Hepatol 2008;6(7):803-6.

7. Casella G, Antonelli E, Bella C, et al. Prevalence and causes of abnormal liver function in patients with coeliac disease. Liver Int 2013:33(7):1128-31.

8. Castillo N, Vanga R, Theethira T, et al. Prevalence of abnormal liver function tests in celiac disease and the effect of a gluten-free diet in the US population. Am J Gastroenterol 2015;110(8):1216-22.

9. Peters U, Askling J, Gridley G, et al. Causes of death in patients with celiac disease in a population-based Swedish cohort. Arch Intern Med 2003;163(13):1566-72.

10. Bardella M, Vecchi M, Conte D, et al. Chronic unexplained hypertransaminasemia may be caused by occult celiac disease. Hepatology 1999;29(3): 654-7. 


\title{
Хронический гепатит, вызванный глютеновой энтеропатией - клинический случай
}

\author{
Ирина И. Иванова ${ }^{1,2}$, Деница Я. Дукова ${ }^{1,2}$, Павлина Г. Бойкова ${ }^{1,2}$, Лили С. Грудева², \\ Иван Б. Шалев ${ }^{1,2}$, Искрен А. Коцев ${ }^{1,2}$ \\ ${ }^{1}$ Кафедра внутренних болезней, Медицинский университет “Проф. Д-р Параскев Стоянов”, Варна, Болгария \\ 2 Клиника гастроэнтерологии, Университетская больница "Св. Марина", Варна, Болгария
}

\begin{abstract}
Адрес для корреспонденции: Ирина И. Иванова, Кафедра внутренних болезней,

Медицинский университет “Проф. Д-р Параскев Стоянов", бул. „Христо Смирненски" 1, 9010 Варна, Болгария

E-mail: irinaiivanova@abv.bg тел: +359888 842505
\end{abstract}

Дата получения: 16 февраля 2016

Дата приемки: 09 ноября 2016 Дата онлайн публикации: 06 марта 2017

Дата публикации: 27 июня 2017

Ключевые слова: глютеновая энтеропатия, гепатит, ферменты печени

Образец цитирования: Ivanova II, Dukova DY, Boikova PG, Grudeva LS, Shalev IB, Kotzev IA. Chronic hepatitis due to gluten enteropathy - a case report.

Folia Medica 2017;59(2):228-231. doi: 10.1515/folmed-2017-0025
Введение: Целиакия является иммунозависимой энтеропатией, вызванная приёмом глютена генетически восприимчивыми лицами.

Описание случая: Представляем случай 45-летней женщины белой расы с тяжёлой формой железодефицитной анемии и незначительным увеличением ферментов печени. Осуществлена верхняя эндоскопия в контексте оценки анемии, которая устанавливает наличие редуцированных складок двенадцатипёрстной кишки и мозаичного типа слизистой оболочки, а также пищеводного варикоза II степени и портальной гипертонической гастропатии. Биопсия двенадцатипёрстной кишки показала полную атрофию ворсинок, диффузный, главным образом лимфоцитарный инфильтрат, наличие интраэпиталиальных лимфоцитов. Серологический тест подтвердил целиакию по наличию типичной модели высокого титра положительных $\lg A$ и $\lg G$ антител в трансглютаминазе ткани. Осуществлена была биопсия печени для определения стадии и этиологической оценки, в силу того, что лабораторный скрининг исключил наличие часто встречающегося вирусного, метаболического и аутоиммунного заболевания печени. Морфология печени соответствовала хроническому гепатиту без наличия находок обширного фиброза. Пациент не соблюдал предписанную диету, что не позволило добиться улучшения ферментов печени и преодолеть анемию в течение контрольного периода.

Заключение: Мы бы хотели отметить многообразие клинических проявлений целиакии и значение серологического скрининга с антителами трансглютаминазы ткани при дифференциальном диагнозе хронической болезни печени. 